\title{
THE DISCOVERING OF EFFECT BETWEEN COMPANY SIZE TOWARD FIRM VALUE WITH INTELLECTUAL CAPITAL IN INDONESIA STOCK EXCHANGE
}

\section{Elly Lestari ${ }^{1}$}

Doctorate Student of Management Department, Faculty of Economics and Business, Universitas Brawijaya, Malang, Indonesia. Lecturer at Universitas Tribhuwana Tunggadewi, Malang, Indonesia,lestariellz@yahoo.co.id

\section{Moeljadi $^{2}$}

Professor of Management Department, Faculty of Economics and Business, Universitas Brawijaya, Malang, Indonesia.,moeljadip@yahoo.com

\section{Sumiati $^{3}$}

Doctor of Management Department, Faculty of Economics and Business, Universitas Brawijaya, Malang, Indonesia. sumiati_atiek@yahoo.com

\section{Djumahir $^{4}$}

Doctor of Management Department, Faculty of Economics and Business, Universitas Brawijaya, Malang, Indonesia. djumahir@fe.unibraw.ac.id

Corresponding Author: Elly Lestari e-mail address: lestariellz@yahoo.co.id

\section{ABSTRACT}

This analysis shown that about company size to firm value and intellectual capital as an intervening variables. This research was used with quantitative methods with conceptual frameworks. Some part of this research is available in Indonesia Stock Exchange registered with companies. There are many things that company can maximize their value such as welfare for labor, profitability, and corporate governance to firm value. Moreover, the intellectual capital is a reflection like uniqueness as a firm value and increase share price in Indonesia Stock Exchange in companies. Additionally, this research can get decision to estimate a results for company values in the future.

\section{Keywords:}

corporate governance, profitability, company size, firm value, intellectual capital

Article Received: 18 October 2020, Revised: 3 November 2020, Accepted: 24 December 2020

\section{INTRODUCTION}

A company value is an achievement in accordance with the wishes of the owners, because with the increase in company value, the welfare of the owners will also increase. For investors, firm value is very important, because increasing firm value shows an increase in shareholder prosperity (Brigham and Houston, 2011). Information related to company financial factors affects the firm value estimate (Tandelilin, 2010). Financial reports are the most common source of information for investment and credit decisions. Financial information is widely believed to be able to move markets and businesses (Lev and Gu, 2016).

Pulic (2000) explains that the firm's market value
(MV) is made not only by the capital used (physical and financial), but also IC by identifying that there is a significant correlation between the mean value of the company's VAIC and MV. According to Pulic (1998), the main objective of a knowledge-based economy is to create added value (VA), while to create a VA requires an exact measure of physical capital and intellectual potential.

Companies are able to manage their intellectual resources effectively and efficiently, their financial performance will improve. Increasing financial performance will have a positive impact on the response from the market so that company value will increase (Ermawati et al., 2017). Intel- 
lectual capital can also contribute to increasing share prices (Feimianti \& Anantadjaya, 2015), which can attract investors and influence investor decisions and company value (Chung and Zhang, 2011). Thus, intellectual capital creates added value as a competitive advantage for companies that can increase company value.

The high profitability of the company is a positive signal for the company's prospects. This shows that the company's goal of prospering shareholders has been achieved, so that it has an impact on high firm value (Brigham and Houston, 2011). Paputungan et al., (2019) in Indonesia founded that intellectual capital has a significant positive effect on firm value. The same results were also found by Utami (2018) in Indonesia and Suherman (2017) in Indonesia.

During 2009 to 2018, there were 40 delisted companies on the Indonesia Stock Exchange. The issues that have surfaced are mostly related to the worrying business continuity. In line with the statement of Lev and Gu (2016) that it is very important to assess a company in achieving and maintaining a sustainable competitive advantage. Companies are important to convey information to investors and potential investors to increase firm value. Information on company financial statements needs to be completed to make it feasible for investment and loan decisions.

Nur'ainy et al. (2013) and Siagian et al. (2013) conducted research on public companies in Indonesia and found that corporate governance increases firm value, which is proxied by tobin's q. The sensitivity analysis with ROA and PBV was carried out by Siagian et al., (2013). Research by Lozano et al. (2016) in 16 European countries and Li et al., (2012) in Russia using market capitalization to measure firm value, found the same result. Using ROA as a measure of firm value. Huang (2010) founded that corporate governance increases firm value. This finding shows the effect of a positive relationship between corporate governance and firm value.

Sucuahi and Cambarihan (2016) was examined 86 companies in the Philippines using tobins'q as a measure of firm value, finding the same results. Likewise, Hermuningsih (2013) who examined 150 companies in Indonesia using tobins'q as a measure of firm value, provides the same empirical evidence. These findings indicated that increasing profitability increases firm value.

Research on company size and firm value relationships has been conducted in several countries and has given mixed results, including Vietnam and Kenya. The results show company size is positively related to firm value as measured by $\mathrm{EV}$, tobins'q, price (Hung et al., 2018). Mule et al., (2015) examined 53 companies in Kenya using tobins'q as a measure of firm value, finding that firm size had no significant effect on firm value.

The part from implementing corporate governance, companies must also pay attention to profitability and company size to increase their Intellectual Capital. Research on profitability to improve intellectual capital has been carried out in India and Malaysia (Pal and Soriya, 2012; Yen et al., 2019). Research on company size affecting intellectual capital has been conducted in Indonesia, Iran, Hong Kong, (Solikhah and Subowo, 2016; Bani et al., 2014; Petty and Cuganesan, 2005, Afshari et al., 2014). However, Bukh (2005) founded that different company size did not affect Intellectual Capital. However, most of the empirical evidence presents company size affecting intellectual capital.

Based on the description above, that intellectual capital is the determinant of firm value, the company's management will always strive for intellectual capital to increase firm value. Corporate governance profitability and company size are important to increase firm value. However, the im- 
plementation of corporate governance in public companies in Indonesia has not shown significant progress. This is also due to the absence of regulations that regulate reporting standards.

This is based on the argumentation that the results of previous studies shown that company size increases intellectual capital. The implementation of company size enhances the company's image, thus

\section{TEORITICAL FRAMEWORK \\ Company Size}

Company size according to Brigham and Houston (2010) is a measure of the size of a company that is indicated or valued by total assets, total sales, total profits, tax expenses and others. According to Hartono (2008) company size (firm size) is the total assets / size of the company's assets using the calculation of the logarithmic value of total assets. Meanwhile, according to Consoladi et al. in Oktaviani (2014) states that: "company size can affect the social performance of the company because large companies have a more distant view, so they participate more in growing the company's social performance".

\section{Intellectual Capital}

Intellectual capital is knowledge that can be turned into profit. Intellectual capital does not only concern the knowledge and skills of employees, but also includes company infrastructure, customer relations, information systems, technology, the ability to innovate and be creative (Maditinos, 2011).

\section{Firm Value}

Firm value is defined as market value because company value can provide maximum prosperity for shareholders if the company's share price increases. Various policies have been taken by management in an effort to increase the value of the company by increasing the prosperity of the owners and shareholders, which is reflected in the share price (Bringham and Houston, 2006). providing opportunities for companies to increase intellectual capital. Based on the background that has been stated, this study aims to develop the financial literature by examining a model that can provide a new understanding of the influence of corporate governance, profitability and company size on intellectual capital and its impact on firm value.

\section{Conceptual Framework}

Based on the theoretical study that has been described previously as well as concepts and empirical evidence from previous research, this section is summarized again briefly to be used as a reference in developing a conceptual research model. Increase in firm value can be done through increasing intellectual capital and the company will always strive for high intellectual capital. It is important for companies to pay attention to corporate governance, profitability and campaign size to achieve these goals. Empirical research shows that high intellectual capital increases firm value (Ermawati et al., 2017; Paputangan et al., 2020; Wang, 2015; Maditinos et al., 2011; Utami, 2018; Suherman, 2017).

The increase in intellectual capital is a reflection of the uniqueness of the firm value. Related to increasing intellectual capital with the implementation of corporate governance, profitability and campaign size, there are 3 things that can be explained. Corporate governance mechanisms, profitability and campaign size can: (1) increasing company performance, because the company has been well managed, resulting in efficiency and effectiveness, as well as increased employee productivity with profitability and company size; (2) increase the company's positive image. Corporate governance, profitability and campaign size forming a positive image of the company; (3) provide opportunities for companies to increase intellectual capital due to increased investor confidence. 
Empirical investigations on the relationship between corporate governance and firm value still vary. Researchers found that corporate governance increases firm value (Huang, 2010; Ammann et al., 2011; Connelly et al., 2012; Li et al., 2012; Nur'ainy et al., 2013; Siagian et al., 2013; Lozano et al., 2016; Villanueva-Villar et al., 2016; Ararat et al., 2017). On the other hand, several other researchers found that corporate governance has a weak role, has no effect, and has a negative effect on firm value (Hidalgo et al., 2011; Jo and Harjoto, 2011; Berthelot et al., 2012; Kumar and Singh, 2013; Mouselli and Hussainey, 2014; Zabri et al., 2015). This finding confirms that the effect of corporate governance in increasing firm value is unclear.

According to legitimacy theory, companies need to have legitimacy in the sense of a social license to operate (Deegan, 2002). This theory shows that companies are involved in sustainability reporting to seek legitimacy and this is very important for companies (Haniffa \& Cooke, 2005). Companies must prioritize stakeholder interests and gain legitimacy in society to achieve long-term sustainability and gain the trust of investors and the public. Investor and public confidence in this longterm sustainability, in turn, increases firm value.

The empirical investigation of the relationship between profitability and firm value still varies. Researchers found that profitability increases firm value (Hung et al., 2018; Kodongo et al., 2014; Sucuahi and Cambarihan., 2016; Hermuningsih., 2013). On the other hand, several other researchers have found the opposite result that profitability reduces firm value (Fernandes and Ferreira., 2007; Anggraini., 2011; Gill et al., 2013; Mukhtaruddin et al., 2014). These findings indicate that there is no clear direction of the relationship between profitability and firm value.

Empirical investigations on the relationship between company size and firm value still vary. Researchers found company size increases firm value (Hung et al., 2018). On the other hand, several other researchers found the opposite result that company size reduces firm value (Mule et al., 2015). These findings indicate that there is no clear direction of the relationship between company size and firm value.

Empirical research provides evidence that profitability can increase intellectual capital (Pal and Soriya., 2012; Yen et al., 2019) and company size can increase intellectual capital (Solikhah and Subowo., 2019; Bani et al., 2014; Petty and Cuganesan., 2005; Afshari et al., 2014). In contrast Bukh et al. (2005) provide empirical evidence that company size reduces intellectual capital. The results of this study do not clearly inform the effect of company size in increasing or decreasing intellectual capital. However, most of the empirical evidence shows that company size increases intellectual capital.

Company size support good business management, thereby increasing intellectual capital. It is expected that intellectual capital will give good signals to investors about the company's performance and have an impact on increasing firm value.

\section{Figure 1. A Conceptual Framework}

\section{Company size $\longrightarrow$ Intellectual Capital $\longrightarrow$ Firm Value}

\section{METHODOLOGY}

The research approach taken is positivism. Posi- tivism is a philosophy of science based on the view that in both social and natural sciences, data www.psychologyandeducation.net 
derived from sensory experience together with the exclusive source of all authentic knowledge, logically and mathematically, obtain "verification" so that it can be accepted as known as empirical evidence. This view is analogous to society operating in accordance with law such as the physical world. Introspective and intuitive attempts to acquire knowledge are rejected. Although the positivist approach has been a recurring theme in the history of western thought, the concept was originally developed in the early $19^{\text {th }}$ century by the founding philosopher and sociologist Auguste Comte. Comte argues that society operates according to its own laws, just as the physical world operates according to the gravity of other natural laws (Comte, 1798-1857 in Martineau, Harriet, 1896).

A suitable approach from this paradigm is a quantitative approach because the data used in this study is a ratio. With the quantitative method, as an effort to justify existing knowledge (science, theory), so that some call it confirmatory research. It is different from research with the qualitative method, namely the effort to find knowledge (science, theory), so that there are those who call it exploratory research. In this study, analysis and prediction are carried out on the influence of corporate governance, profitability and company size on firm value with the intervening intellectual capital variable in companies listed on the Indonesia Stock Exchange.

\section{Population and Research Sample}

The company is listed on the Indonesian Stock Exchange (IDX) for the period 2012 - 2018. Publish a corporate governance report contained in the annual report 2012 - 2018 and can be accessed through the Indonesia Stock Exchange (IDX) website and the company's official website. The company is presents a complete financial report for 2012 - 2018 in rupiah currency, this criterion is intended so that researchers do not make adjustments that are feared to cause miscalculations and interpretations.

\section{Types and Sources of Data}

The type of data in this study is quantitative data and secondary data is used in this study, which is taken from the annual reports of public companies in Indonesia from 2012 to 2018. The company's annual reports include: annual reports, sustainability reports. , corporate governance reports, and financial reports. All data is taken from ICMD publications, the Indonesia Stock Exchange website, company websites, and other media (http://finance.yahoo.com and http://ticmi.com). Annual reports published by the company are used in this study because they have high credibility and are used by stakeholders as a source of information (Deegan and Rankin, 1997).

\section{Classification of Research Variables}

Based on the conceptual framework described earlier, there are three independent variables in this study, namely Corporate Governance, Profitability and Company Size and one dependent variable, namely Firm Value. Meanwhile, the intervening variable was Intellectual Capital.

\section{Descriptive Analysis Method}

Using descriptive statistics with the aim, to analyze the collected data as it is without intending to make general or generalized conclusions. By using descriptive statistical analysis can provide a description of all research variables.

\section{Structural Equation Model - Partial Least Square (PLS)}

Data analysis was performed using Partial Least Square (PLS) analysis and path analysis (parth analysis). PLS (Partial Least Square) is a model an alternative to covariance based SEM. PLS were intended for causal predictive analysis with high complexity situations and low theory support (Ghozali, 2014). The purpose of PLS is to find the optimal predictive linear relationship that exists in 
the data. Although PLS can also be used to confirm a theory, it can also be used to explain whether or not there is a relationship between latent variables. As stated by Wold in Ghozali (2014) Partial Least Square (PLS) is a powerful analysis method because it is not based on many assumptions, the data does not have to be normally distributed multivariate, and the sample does not have to be large.

\section{REFERENCES}

[1] Afshari, Vahid, Javid, Dariush, Soleimani, Hossein, and Afshari, Hossein. (2014). To Study The Relationship Between Intellectual Capital and Financial Performance of Companies in Capital Market of Iran. Kuwait Chapter of Arabian Journal of Business and Management Review. 4(1), 247266.

[2] Ararat, Melsa, Black, Bernard S., and Yurtoglu, B. Burcin. (2017). The effect of corporate governance on firm value and profitability: Time-series evidence from Turkey. Emerging Markets Review, 30, 113-132.

[3] Berthelot, Sylvie, Francoeur, Claude, and Labelle, Re'al. (2012). Corporate governance mechanisms, accounting results and stock valuation in Canada. International Journal of Managerial Finance, 8(4), 332343.

[4] Brigham, Eugene F, and Daves, Phillip R. (2011). Intermediate Financial Management. United States: Thomson Higher Education.

[5] Brigham, Eugene F, and Houston, Joel F. (2010). Dasar-Dasar Manajemen Keuangan. Edisi 11. Jakarta: Salemba Empat.

[6] Brigham, Eugene F, and Houston, Joel F.(2011). Manajemen Keuangan. Jakarta: Erlangga.

[7] Buallay, Amina, and Hamdan, Allam. (2019). The relationship between corporate governance and intellectual capital The moderating role of firm size. International
Journal of Law and Management, 61(2), 384-401.

[8] Connelly, J. Thomas, Limpaphayom, Piman, and Nagarajan, Nandu J. (2012). Form versus substance: The effect of ownership structure and corporate governance on firm value in Thailand. Journal of Banking \& Finance, 36, 1722-1743.

[9] Ermawati, Yana, Noch, Muhamad Yamin, Zakaria, Ikhsan, Arfan, and Khaddafi, Muammar. (2017). Reconstruction of Financial Performance to Manage Gap between Value Added Intellectual Coefficient (VAICTM) and Value of Company in Banking Company Listed in Indonesia Stock Exchange. International Journal of Economics and Financial Issues, 7(4), 537549.

[10] Feimianti, E., and Anantadjaya, S. P. (2015). Value Creation of Intellectual Capital : Financial Performance Analyses in Indonesian Publicly- Listed Consumer Goods Industry. Review of Integrative Business \& Economics Research, 3(1), 99-113.

[11] Gherghina, Ştefan Cristian. (2015). Corporate Governance Ratings and Firm Value: Empirical Evidence from the Bucharest Stock Exchange. International Journal of Economics and Financial Issues, 5(1), 97110.

[12] Gill, Amarjit, Biger, Nahum, Mand, Harvinder S, and Mathur, Neil Arun. (2013). Earnings Management, Firm Performance, and the Value of Indian Manufacturing Firms. International Research Journal of Finance and Economics. Issue, 116

[13] Guenter Blendinger, Grzegorz Michalski. (2018). Long-Term Competitiveness Based On Value Added Measures As Part Of Highly Professionalized Corporate Governance Management Of German Dax 30 Corporations. Journal Of Competitiveness. Vol. 10, Issue 1, Pp.5-20,June2018. 
Issn 1804-171x (Print), Issn 1804-1728 (On-Line), Doi: 10.7441/Joc.2018.02.01

[14] Jamei, Reza. (2017). Intellectual Capital and Corporate Governance Mechanisms: Evidence from Tehran Stock Exchange. International Journal of Economics and $\mathrm{Fi}$ nancial Issues, 7(5), 86-92.

[15] Lev, Baruch, and Gu, Feng. (2016). The End of Accounting and the Path Forward for Investors and Managers.

[16] Li, Wei Xuan, Chen, Clara Chia Sheng, and Frech, Joseph J. (2012). The relationship between liquidity, corporate governance, and firm valuation: Evidence from Russia. Emerging Markets Review, 13, 465-477.

[17] Lozano, M.Belén, Martínez, Beatriz, and Pindado, Julio. (2016). Corporate governance, ownership and firm value: Drivers of ownership as a good corporate governance mechanism. International Business Review, 25, 1333-1343.

[18] Lukviarman, Niki. (2016). Corporate Governance: Menuju Penguatan Konseptual dan Implementasi di Indonesia. Fakultas Ekonomi Universitas Andalas: PT. Era Adicitra Intermedia.

[19] Mouselli, Sulaiman, and Hussainey, Khaled. (2014). Corporate governance, analyst following and firm value. Corporate Governance, 14(4), 453-466.

[20] Paputungan, Rahmita Dwinesia, Subroto, Bambang, and Ghofar, Abdul. (2020). Does institutional ownership moderate the effect of intellectual capital and company value? International Journal of Research In Business And Social Science, 9(1), 127-136.

[21] Salisu, Umar, Ishak, Zuaini, and Sawandi, Norfaiezah. (2019). Corporate Board and the Value of Diversified Public Listed Companies in Malaysia. Journal of Business and Retail Management Research (JBRMR), 13(3), 36-42.

[22] Solikhah, Badingatus, and Subowo. (2016).
An Empirical Study of the Driver Factors of the Intellectual Capital Disclosure. Review of Integrative Business and Economics Research, 5 (1), 229-240.

[23] Sucuahi, William, and Cambarihan, Jay Mark. (2016). Influence of Profitability to the Firm Value of Diversified Companies in the Philippines. Accounting and Finance Research 5(2).149-153.

[24] Sudana, I Made. 2011. Manajemen Keuangan Perusahaan Teori dan Praktek. Jakarta: Erlangga.

[25] Suherman, Richard. (2017). The Impact of Intellectual Capital toward Firm's Profitability and Market Value of Retail Companies Listed in Indonesia Stock Exchange (IDX) from 2013-2016. iBuss Management, 5 (1), 98-112.

[26] Utami, Eristy Minda. (2018). The Intellectual Capital Components on Firm Value: Evidence from LQ-45 Index Companies. Jurnal Keuangan dan Perbankan, 22(2), 291-300.

[27] Villanueva-Villar, Mónica, Rivo-López, Elena, and Lago-Penas, Santiago. (2016). On the relationship between corporate governance and value creation in an economic crisis: Empirical evidence for the Spanish case. BRQ Business Research Quarterly, 19, 233- 245.

[28] Yan, Xiaochang. (2017). Corporate governance and intellectual capital disclosures in CEOs' statements. Nankai Business Review International, 8(1), 2-21.

[29] Yen, Sia Beng, Lee, Chong Aik, and Arokiasamy, Lawrence. (2019). The Moderating Effect of Multinationality on Intellectual Capital - Profitability Relationship of Malaysian Banks. Global Business and Management Research: An International Journal, 11(1), 560-570.

[30] Zogning, Félix. (2017). Agency Theory: A Critical Review European Journal of Business and Management 9(2), 1-8 
